\title{
Fantasy, A Means to Propagate Ideologies: A Foucauldian Reading of Albee's The Zoo Story
}

\author{
Bahee Hadaegh (Corresponding author) \\ Shiraz University, Iran \\ E-mail: bhadaegh@rose.shirazu.ac.ir \\ Hamid Reza Pilehvar \\ Shiraz University, Iran \\ E-mail: hr.pilehvar@gmail.com
}

Received: 18-08-2016

Published: 10-12-2016
Accepted: 15-10-2016

doi:10.7575/aiac.ijalel.v.5n.7p.147
Advance Access Published: November 2016

URL: http://dx.doi.org/10.7575/aiac.ijalel.v.5n.7p.147

\begin{abstract}
Fantasy is a genre in literature which embodies wishes and desires of human beings. Due to such features, it has been turned into a means by which different discourses utilize fantasy as a way to propagate their ideologies. This happens because fantasy is capable of providing each discourse with a concrete image of their promises to their subjects. The aim of this essay is to delve into Albee's The Zoo Story, using a Foucauldian reading, to show that American dream as a discourse is not the only existing discourse within the society of America, but there are other marginalized voices in the form of fantasies in which power circulates. Peter, the mouthpiece of American dominant discourse, has a fantasy created by that discourse which is in stark contrast to that of Jerry, the marginalized discourse existing along with the dominant one, which threatens the dominant discourse and struggles to reach the peak in the power structure.
\end{abstract}

Keywords: Discourse, Power, Foucault, Fantasy, American dream, Marginalized Voices, Albee, The Zoo Story

\section{Introduction}

Undoubtedly, Edward Albee is one of the greatest American playwrights who, alongside with Williams, O'Neill, and Miller, shoulders the burden of the causes of American contemporary drama, and it is "estimated in 1966 that 80 per cent of the submissions on American drama were about [these] four authors" (Weales 23). Even President Bill Clinton in 1996 aptly summarized Albee's achievement by declaring to the playwright, "In your rebellion, the American theater was reborn" (qtd in Burt 293).

Edward Albee tries to explore new problems of humanity in each of his plays, and each play "seems to be an experiment in form, in style (even if it is someone else's style), and yet there is unity in his work as a whole" (Weales 24). However, James L. Roberts declares, "In Edward Albee's plays, each character is existing in his own private ego" (11). Therefore, the similarity in much of Albee's works is the depiction of the loneliness and emptiness of his characters' states of feeling.

Albee became well-known with his first one-act play The Zoo Story in 1958. He criticizes his contemporary society and lifestyle in this play, moreover, "[t]he target of his criticism is the dominant culture of his time for which Peter acts as a representative" (Shams and Pourgiv 2). The Zoo Story contains themes which would dominate Albee's subsequent works, "including the shattering of complacency, the connection between love and aggression, and the relationship between fantasy and reality" (Burt 294). Albee, as a social critic, attacks the world "that makes conformism a virtue and inconformism a vice, a sickness, a kind of madness" (Sigrid 178). According to Albee, human's truth is "not to be found in society's platitudes or the promises of social conformity" (Saddik 37).

Among the ideas of Edward Albee the questions of gender, family, power, women, and human relationships were the significant and ubiquitous ones. Albee in The Zoo Story "attacked the very foundations of American idealism" (Saddik 36). The Zoo Story is a play which best represents, in Albee's corpus, the clash between the two kinds of fantasies.

\section{Methodology: Foucauldian Notion of Discourse and Power}

Foucault is a philosopher who believes that all the social relations are constructed upon the struggle over power. "Foucault's bottom-up model of power, that is his focus on the way power relations permeate all relations within a society" (Mills 34). Therefore, each individual, belonging to one specific discourse, exists in the power structure, and he is able to make alterations to this hierarchy. This type of approach toward history and society "allows an analysis which focuses on individuals as active subjects, as agents rather than as passive dupes" (ibid).

Discourse in Foucault's opinion governs and controls the production of knowledge within its domain. In Foucault's beliefs physical objects exist out of our will, independence from the discourses, but how we apprehend and interpret these phenomena is within a discursive structure. 
The fact that every object is constituted as an object of discourse has nothing to do with whether there is a world external to thought ... An earthquake or the falling of a brick is an event that certainly exists, in the sense that it occurs here and now, independently of my will. But whether their specificity as objects is constructed in terms of 'natural phenomena' or expressions of 'the wrath of God' depends on the structuring of a discursive field. What is denied is not that such objects exist externally to thought, but the rather different assertion that they could constitute themselves as objects outside any discursive condition of emergence. (qtd in Mills 56)

Therefore, when Foucault talks about discourse, he is focusing on the constraints and restrictions. That is, one can utter infinite number of utterances, but they are all produced within a finite and narrowly confined limitations of the discourse in which one is uttering.

Foucault's main objective as a historian is to discover the marginalized voices in the history, and "to re-do the things said by traditional records of history so that the 'interior secret' and the other history that runs beneath those records and is more fundamental would be uncovered" (Foucault 1972:22). To identify the "interior secret" and the "initiating subjectivity" of a historical era, he attempts to "discover the law operating behind" (Foucault 1972:50) the dominant discourse of the era that "is constituted by a group of sequences of signs, in so far as they are statements, that is, in so far as they can be assigned particular modalities of existence" (ibid 106).

The notion of power is of utmost importance in Foucault's ideas. He believes that "power circulates in all directions" (Tyson 284). It is just like a chain, and it does not remain in one direction and the relation with people within a given community is complex and it is not "a set of relations between the oppressed and the oppressor" (Mills 35). In opposition to many other theorists, "he asserts that power is not the privilege of the dominant class; rather it comes from innumerable points" (Farshid \& Sokhanvar 7). Therefore, the individuals are not just the subjects to power, rather they may actively play a role in resisting the power which is embodied in the form of institutions.

In Foucault's opinion, power is not located in one single specific institution, instead he believes in the existence of various forms of discourses struggling over power. Not only does Foucault believe in simultaneous existence of discourses, but he also claims that power is not necessarily a constraining factor. In History of Sexuality he says: "if power was never anything but repressive, if it never did anything but say no, do you really believe that we should manage to obey it?" (36). It is implied from this quotation that power has a constructive feature in itself as opposed to conventional Marxist and Feminist tradition which consider power as a restrictive and oppressive force.

Thus, in Foucault's ideas, no discourse is ever able to have very long validity. He believes the way in which discourses are formed "does not play the role of a figure that arrests time and freezes it for decades or centuries" (Foucault 1978:74). His reasons for this claim is as follows:

there is no statement in general, no free, neutral, independent statement; but a statement always belongs to a series or a whole, always plays a role among other statements, deriving support from them and distinguishing itself from them; it is always a part of a network of statements. (Foucault 1978:99)

How a discourse comes to the top of hierarchy of power is a complicated process. All the institutions within the discourse work together to exclude the statements which they categorize as false and which do not conform to their discourse. If one wants to remain in the domain of a specific discourse, one must comply with the rules of that discourse. In The Archeology of Knowledge, he states that "it is always possible one could speak the truth in a void; one would only be "in the true" however if one obeyed the rules of some discursive "police" which would have to be reactivated every time one spoke" (224).

\section{Discussion}

Fantasy, as a literary genre, is the one which has been always present in social and literary discussions, but has been frequently denigrated by scholars and theorists. This denigration and lack of critical attention to it was owing to the fact that quite a lot of critics relegate this genre to the realm of children's literature, consequently, unworthy of critical responses. The importance of fantasy is seriously overlooked.

However, many theorists of fantasy believe that this genre possesses consistent laws which contribute to real life. This idea is further elaborated by George MacDonald in his essay titled "The Fantastic Imagination". The elements of unreal and magic is indispensable parts of fantasy which Le Guin thinks it "[helps] readers cope with the real world by allowing them to view it in a different way. Fantasy, writes Le Guin, is a journey into the reader's subconscious, and "it will change you." (Patti 574). On the other hand, some critics and authors composed many defenses of fantasy, as an example, C.S. Lewis stresses that the sensations and elements found in fantasy are not at all arbitrary, but they are all preplanned for some effects. Fantasy, he sums up, gives readers "experiences [they] have never had and this, instead of 'commenting on life,' can add to it" (Patti 575).

As mentioned above, fantasy, not even as a literary genre but as a tool in every walk of life, has its own existence separated from real life orders and laws, therefore, it has been utilized by human kind to convey and consolidate their views of everything to others. Besides, "new fantasies, for in some way or other the human imagination seems driven to fill the vacuum" (Smith 305). Although fantasy is itself a discourse, it is used in different discourses like the discourse of science, the discourse of politics, and the discourse of religion to create a dream, making the aim of that specific 
discourse as tangible as possible for the subjects. For instance, religious discourse of all kind uses fantasy to create a fixed and consolidated picture of God and the hereafter. "Heaven, with its gates of pearl and streets of gold, its ordered ranks of angels and cherubim's, and hell's yawning chasms and hierarchy of demons, were naturally fantasies in themselves" (Smith 305). In this fantastic picture of hell every detail is enumerated and depicted to create a concrete image and mental picture of the hell. Therefore, the dominant discourse or the discourse in power uses the discourse of fantasy to pave the way to its end.

Besides, fantasy oscillates between the realist and the anti-realistic, or 'the mimetic' and 'the marvelous'. With this feature it is able to "[threaten] to subvert (overturn, upset, undermine) rules and conventions taken to be normative" (Bechtel 144) and to create "an ellipse of uncertainty" (Bechtel 145) in the text. Hence, in this sense and from postmodern viewpoint, fantasy is equated with deconstructionism, "for it interrogates all we take for granted about language and experience, giving these no more than a shifting and provisional status" (ibid). In the case of American dream, it is also a discourse which uses fantasy as a tool to create a mental picture of its promises in the minds of its subjects.

The term 'American dream' was introduced by the American Historian James Truslow in the period during which the United States were suffering from the Great Depression of the 30s. Truslow uses the term to describe political and social expectations, religious promises, and fortune promises. American dream, similar to many other discourses use fantasy in propagating its ideologies. The central motif in American dream is the common cliché, "the rise from rags to riches" (Lemay 23). Therefore, it fantasizes a future full of prosperity in the land of opportunities. But one must caution that American dream is not just the dream of accumulating wealth, but a dream "of the manifold possibilities that human existence can hold for the incredible variety of people of the most assorted talents and drives (Lemay 25).

It is believed that American dream has its roots in the Declaration of Independence, because the basic idea embedded in it is that every individual heedless of race, family background, class, etc. is likely to reach achievements, and in this sense, American dream, on this archetypal level, embodies a universal experience" (Lemay 25). In this context, Benjamin Franklin's Autobiography is a cornerstone in giving a definitive formulation to American dream. In this book, the most important aspects of American dream like "the rise from impotence to importance, from dependence to independence, from helplessness to power" (Lemay 24) are enumerated.

The fantasy of American dream is repeatedly echoed in many works of contemporary American Literature. However, most of the works depict the failure of the fantasy created by American promise of prosperity because of its overinsistence on materialism, and pinpoint the existence of other discourses alongside with it. Among a large number of works in this regard, that of Arthur Miller is outstanding.

Arthur Miller clearly delineates the failure of this fantasy in his character of Willie Lowman in Death of the Salesman. The fantasy created by American dream's discourse keeps Willie apart from reality and makes a sort of "inability to remain psychologically in the here and now" (Moseley 48). The fantasies making a false dream of success are evident throughout the whole play such as the idea of being "well-liked" embraced by Willie as a prerequisite to success. Harold Clurman (qtd in Moseley) in his influential early review on the play says:

Death of a Salesman is a challenge to the American dream. Lest this be misunderstood, $i$ hasten to add that there are two versions of the American dream. The historical American dream is the promise of a land of freedom with opportunity and equality for all. This dream needs no challenge, only fulfillment. But since the civil War, and particularly since 1900, the American dream has become distorted to the dream of business success. A distinction must be made even in this. The original premise of our dream of success-popularly represented in the original boy parables of Horatio Alger — was that enterprise, courage and hard work were the keys to success. Since the end of the First World War this too has changed. Instead of Arthur miller the ideals of hard work and courage, we have salesmanship. Salesmanship implies a certain element of fraud: the ability to put over or sell a commodity regardless of its intrinsic usefulness. The goal of salesmanship is to make a deal, to earn a profit - the accumulation of profit being an unquestioned end in itself. (52-53)

In addition, Happy's fantasy is similar to Willie's in that it is the product of American dream, and his fantasy, like that of Willie, is in a harsh conflict with that of Biff, which is the antithesis to American dream fantasy. The fantasy of American dream discourse is in stark contrast to Biff's fantasies which are created by, in Foucault term, "other history". In addition, these two fantasies are in struggle with each other over reaching power. The failure of American dream is articulated when Biff says: "Will you let me go, for christ's sake? Will you take that phony dream and burn it before something happens?" (Miller 133). The conflict between these two fantasies are apparent in the characters of Biff and Happy, most noticeably in the Willy's burial, which Miller called "Requiem":

Biff: He had the wrong dreams. All, all, wrong.

Happy, almost ready to fight Biff: Don't say that!

Biff: He never knew who he was. (138)

As one could witness in the work mentioned above, different discourses exist alongside with each other. Although American dream and its related ideology was the dominant discourse, other discourses were in the hierarchy of power. In other words, "there is no monolithic (single, unified, universal) spirit of an age, and there is no adequate totalizing 
explanation of history (an explanation that provides a single key to all aspects of a given culture)" (Tyson 285). In short, In Miller's Salesman, Biff embodies a fantasy as opposed to American dream fantasy.

Similarly in The Zoo Story, Albee depicts the clash between two individuals, Peter and Jerry, the former has assimilated into the power structure and hierarchy, and has been living in his self-built private territory, and the latter, who is unprivileged within the same society, disrupts the societal norms and "tries to shake Peter out of his role and resists the unjust system that victimized both him and Peter" (Shams and Pourgiv 2). This struggle and clash between Peter and Jerry symbolizes the clash between two existing discourses over power both of which contain fantasies; Peter has the fantasy of American dream, and Jerry has a fantasy of marginalized groups. Peter is immersed in materialism and is doing very well in his role in this materialistic atmosphere: An Upper East Side house, wife, children, TV, eighteen thousands a year. What Peter is doing in his life is to maintain his routine no matter what happens. This is evident from the fact that every Sunday he goes to the park to read the newspaper. All in all, his fantasy is limited to a material form which tries to exclude the other opposing fantasies.

However, Jerry's fantasy is totally of a different kind. He has a fantasy in which everyman is released of his own barred existence, that is why he tries to establish some communications. "It probably wasn't a fair test, what with everyone separated by bars from everyone else, the animals for the most part from each other, and always the people from the animals" (Albee 20). The desire which Jerry is perusing is that he "wants to learn to love, but what he has learned about himself and love is unacceptable" (Heldreth 26) through the lens of American dream fantasy.

Of course, Albee is the one who takes side with the fantasy existing along with but opposed to American dream fantasy, since he has Jerry criticize Peter's way of living affected by American dream discourse. He acknowledges in his Preface to The American Dream, "[the play is] an attack on the substitution of artificial for real values in our society" (qtd in Weales 27). This idea can be extended to The Zoo Story in which Peter's lifestyle is completely criticized. The attack Albee goes on "is implicit in the depiction of Peter in The Zoo Story" (Weales 27). Albee makes Peter the subject of satire owing to the fact that "[Peter] has surrendered himself to his role" (Stenz 8). But as mentioned above, Jerry's fantasy is not at all materialistic, or more precise to say they are out of the dominant discourse. This is the very explanation why Peter and Jerry cannot understand each other. "It is difficult, if not impossible, to think and express oneself outside these discursive constraints because, in doing so, one would be considered to be mad or incomprehensible by others" (Mills 57).

Although Fantasy exists embedded in Jerry's discourse, it does not have any power to go up within the power structure. He himself acknowledges in the play that "it's necessary to go a long distance out of the way in order to come back a short distance correctly" (Albee 8). Jerry is an individual who has defied the social norms; as a result, he has "become a recluse" (Shams and Pourgiv 3). Like Peter, Jerry cannot have a family, wife, a good house in a good district, children, etc. The dominant discourse, American dream, uses all the other discourses, including Jerry's discourse and discourse of fantasy, to maintain its power, but Jerry's fantasy can exert a threat to and resist the dominant discourse: "discourses wield power for those in charge, but they also stimulate opposition to that power" (Tyson 285).

Jerry expresses his hatred of the west side of the park, and when Peter threatens to call a police man, Jerry replies "they are all over on the west side of the park chasing fairies" (Albee 22). The interesting point is that Jerry also lives on the west part of the park, therefore, he is trying to "[associate] himself with the West" (Heldreth 25). But this abhorrence might be because his repression of homosexuality in his adolescence is done in the West.

As mentioned earlier, Jerry is living in a society whose discourse does not agree with his fantasy. Due to this harsh reality, Jerry recalls the past when he was having a relationship with the park superintendent's son. That is because his present situation cannot satisfy his needs and fantasies, and he wants to recapture the delightful and ecstatic experiences from the past. Jerry says adults "use real experience as a substitute for the fantasy" (Albee 11). This sentence "criticizes a world that cannot live up to his fantasy expectations and indicates a desire for another relationship as valid as that with the Greek boy" (Heldreth 23).

The struggle between the fantasies, those of Peter and Jerry, starts with the fight over the possession of the bench in the park through which "[Jerry] he can overthrow the structure of power, which has excluded him from social life" (Shams and Pourgiv 3). Jerry has a tendency to destroy Peter's fantasy and illusion of being in a stable life using violence and he "attempts to awaken Peter from his dependence on material things to teach him the destructiveness of his illusions" (Aliakbari 19). And Jerry is doing this by beginning the conversation with hypnotic effects on Peter, which includes his actions and gestures.

PETER. [Laughing faintly] You're ... you're full of stories, aren't you?

JERRY. You don't have to listen. Nobody is holding you here; remember that. Keep that in your mind.

PETER. [Irritably] I know that. JERRY. You do? Good. [The following long speech, it seems to me, should be done with a great deal of action, to achieve a hypnotic effect on Peter... the director and the actor playing JERRY might best work it out for themselves.]. (Albee 13)

When there is no reconciliation between the two fantasies, the nature of power entails a harsh struggle, as Edward Albee and Thomas P. Adler (1973) assert that "if love does fail then one must be willing to hurt the other person in order to reach him" (67). After talking fails, Jerry resorts to violence over possession of the bench.

JERRY. ... I went to the zoo to find out more about the way people exist with animals, and the way animals exist with each other, and with people too. It probably wasn't a fair test, what with everyone separated by bars 
from everyone else, the animals for the most part from each other, and always the people from the animals. But, if it's a zoo, that's the way it is. [He pokes Peter on the arm.] Move over.

PETER. [Friendly] I'm sorry, haven't you enough room?

[He shifts a little.]. (Albee 20)

Jerry further intrudes the privacy of Peter by inquiring into the decision of having no more children.

PETER: [A bit distantly] No. No more. [Then back, and irksome] Why did you say that? How would you know about that?

JERRY: The way you cross your legs, perhaps; something in the voice. Or maybe I'm just guessing. Is it your wife?

PETER: [Furious] That's none of your business! [A silence.] Do you understand? [JERRY nods. PETER is quiet now.] Well, you're right. We'll have no more children. (Albee 5)

The further probing into Peter's private life causes Peter to admit his disillusionment with his life, saying: "we'll have no more children" (Albee 5). Nonetheless, Peter's representative family "is as or even more dangerous than individual alienation because it serves to mask alienation without remedying it" (qtd in Aliakbari 15). And exactly at this moment, one can witness how power is circulating among the existing discourses. The once-dominant discourse of American dream is run over by another discourse again in a form of fantasy. Thus, finally, because of this lack of compromise and reconciliation between the two discourses, the dominant discourse is struggling against any resistance and tries remain in the position of power; this is evident in the play when "Peter, the conformist in The Zoo Story, is provoked into killing Jerry, the individualist” (Roberts 11).

At the end, although Jerry is dead, this does not mean that he is finished. He still remains in Peter's memory for good, and as Jerry himself acknowledges to Peter: "And now you know what you'll see in your TV, and the face I told you about ... you remember ... the face I told you about ... my face, the face you see right now." (Albee 26). Besides, Albee himself acknowledges that "by dying Jerry passes on an awareness of life to Peter" (Stenz 11), and in that suicidal act, "Jerry becomes a scapegoat who gives his own life so that Peter will be knocked out of his complacency and learn to live, or LIVE" (Weales 29). Thus, by acknowledging this Albee has set the play free from the accusations of being nihilistic and pessimistic. By the same token, one can say that the fantasies related to American dream are challenged by the later existing fantasies because "[a]fter his death, Jerry will be talked of and seen, and this is exactly what he aims to achieve" (Shams \& Pourgiv 3).

Jerry sacrifices himself to show Peter that the life Peter is leading is a shallow type which is all an illusion. In this sense: "[Jerry] is a Christ figure or a prophet. In so far as there is teaching and sacrifice, and the implication of salvation for Peter through awareness, on the symbolic level Jerry may be identified with Christ" (Stenz 6). Acting like Christ, and sacrificing himself is the only last alternative through which Jerry "can make Peter shed his bourgeois self-indulgence and experience some kind of communication" (Aliakbari 20).

\section{Conclusion}

Discourses shape the worldview of the individuals within a given society. According to Foucault, there is not a single discourse existing in a specific era, but there are several ones existing simultaneously. There is always a struggle over power among all the discourses, therefore, all of the marginalized discourses can play roles in the hierarchy of power. Hence, power does not remain in one specific institution. The fact is that, all these discourses contain elements of fantasy and use the discourse of fantasy for elucidating their ends. Hence as was argued throughout the paper, they are fantasies which are struggling with each other over power. When The Zoo Story was acted in 1958, the dominant discourse of American society was the discourse of American dream which, in many authors' view, was a failure. It was argued throughout the paper how Edward Albee, as a social critic, tries to depict the existence of other discourses simultaneous with American dream discourse, and how all the discourses struggle to go up in the power structure. At the end of the paly when Jerry impales himself on the knife, the final assault of the fantasy of marginalized discourse on the fantasy of dominant discourse is clear, and has a long-lasting effect on the fantasy of Peter or American dream.

\section{References}

Albee, Edward. The Zoo Story. New York: Samuel French, 1959. Print.

Albee, Edward \& Adler, T. P. “Albee's who's afraid of Virginia Woolf? A long night's Journey into Day”. Educational Theatre Journal. 25, 66-70, 1973. Pdf.

Aliakbari Harehdasht, Hossein and et al. "Illusion and Reality in Edward Albee's The Zoo Story". Studies in Literature and Language. Vol. 10, No. 6, 2015, pp. 15-21. Pdf.

Bechtel, Greg. “There and Back Again”: Progress in the Discourse of Todorovian, Tolkienian and Mystic Fantasy Theory". ESC 30.4 (December 2004): 139-166. Pdf.

Burt, Daniel S. The Drama 100. New York: Infobase Publishing, 2008. Pdf.

Farshid, Sima \& Sokhanvar, Jalal. “A Foucauldian Reading of Morrison's Novels”. International Journal of Arts and Sciences. 3(10): 295 - 311. Pdf. 
Foucault, Michel. The Archeology of Knowledge. New York: Tavistock Publishing, 1972. Pdf.

----. The History of Sexuality, Vol. I: An Introduction, (trans. Robert Hurley), Harmondsworth: Penguin, 1978. Pdf.

Heldreth, Leonard G. "From Reality to Fantasy: Displacement and Death in Albee's Zoo Story". Ed. Langford, Michele K. Contours of the Fantastic. CT: Greenwood Press, 1990: pp. 19-28. Pdf.

Lemay, J.A. Leo. “Franklin's Autobiography and the American Dream”. Bloom's Literary Themes: The American Dream. Ed. Bloom, Harold. New York: Infobase Publishing, 2009: pp. 21-36. Pdf.

Miller, Arthur. Death of a Salesman: Certain Private Conversations in Two Acts and A Requiem. New York: Viking, 1949. Print.

Mills, Sara. Michel Foucault. New York: Routledge, 2003. Pdf.

Moseley, Merritt. “Arthur Miller's Death of a Salesman”. Bloom's Literary Themes: The American Dream. Ed. Bloom, Harold. New York: Infobase Publishing, 2009: pp. 47-55. Pdf.

Patti, J. Kurtz. "Understanding and Appreciating Fantasy Literature". Choice, 40 (04), 2007: pp. 571-580. Pdf.

Roberts, L. James. CliffsNotes ${ }^{\mathrm{TM}}$ Who's Afraid of Virginia Woolf?. New York: Hungry Minds, 1979. Pdf.

Shams, Parisa \& Pourgiv, Farideh. "Power Struggle in The Zoo Story: A Performance of Subjectivity". Fe Dergi 5, no.1 (2013): pp. 1-11. Pdf.

Sigrid, P. M. “The Two Opposing Forces in Albee's The Zoo Story”. Journal of Language, Linguistics, and Literature, vol. 2, No. 1, 2016: pp.178-194.

Smith, Harrison. "The Rise of Fantasy in Literature”. The American Scholar, Vol. 17, No. 3 (SUMMER 1948): pp. 305312. Pdf.

Stenz, M. Anita. Edward Albee: The Poet of Loss. New York, Mouton Publisher, 1987. Print.

Tyson, Lois. Critical Theory Today. New York: Routledge, 2006. Print.

Weales, Gerald. "Edward Albee: Don't Make Waves". Modern American Drama. Ed. Bloom, Harold. New York: Chelsea House Publishers, 2005: pp. 21-44. Pdf. 